\title{
Effect of the Composition of Non-metallic Inclusions on \\ the Rusting of Ferritic Stainless Steels*
}

\section{By Noboru KINOSHITA, ,* Nobuo OHASHI ${ }^{* * *}$ and Motohiko TAKEDA ${ }^{* * *}$}

\begin{abstract}
Synopsis
On the $17 \% \mathrm{Cr}$ stainless steel strips commercially melted and processed, the effects of aluminum content and composition of non-metallic inclusions on the rust resistance during the exposure in salt fog have been investigated.

The observations under an optical microscope and a scanning electron microscope and the micro-analyses with an electron probe $X$-ray analyser on the specimens after the brief exposure in salt fog show that pitting corrosion initiates due to the dissolution of calcium-rich sulfides which exist like shells surrounding aluminate inclusions. Iron dissolves from inner surface of a pit resulting from dissolution of the sulfides, which lead to a ring-like rust around the pit.

The proportion of the number of these water-soluble inclusions increases with aluminum content of the steels.
\end{abstract}

\section{Introduction}

For the wide use of $17 \% \mathrm{Cr}$ stainless steel strip (AISI-430) as automotive trim and kitchen utensils, etc., the forming properties and corrosion resistance of the steel have been extensively investigated. Especially, on the bending property around the axis parallel to the rolling direction of strip, which is a very important factor for the forming performance, detailed studies have been performed and it has been clarified that this property is deteriorated by stringer-like inclusions such as silicates. ${ }^{1,2}$

On the other hand, the corrosion resistance, especially the rust resistance of the steel has been examined only by the practical testing methods, for example by atmospheric exposure and by mounting the specimens underneath the automobile, and the mechanism of the rusting has not been clarified in details.

Stainless steels keep their corrosion resistance substantially by passive film on their surfaces. Therefore the steel making or forming processes in connection with surface conditions are essentially important. Bright annealed strip is more resistant to corrosion than the butane-fire annealed and pickled strip, because the surface of the strip is free from socalled chromium depletion zone. However, the report by Carnegie and Moskowitz ${ }^{3)}$ stating that the bright annealed strip is scarcely suffered from etch corrosion but is subjected to pitting corrosion should be noticed.

During the investigation of the bending property of $17 \% \mathrm{Cr}$ stainless steel, present authors have found ${ }^{4)}$ that the steel which possesses good bendability often experiences serious rusting during the use in corrosive environments. They also found that the rust resistance of cold rolled and bright annealed strip is af- fected not only by the contents of main alloying elements, and rolling and annealing conditions but also, more basically, by the deoxidation practice of molten steel and the variation in the composition of nonmetallic inclusions in the steel.

Recently, some studies have reported the effect of non-metallic inclusions on the corrosion resistance of stainless steels, but on the commercial 17\% Cr stainless steel this effect has not been examined as yet. Under these circumstances, it seems very important to make clear the effects of inclusions and the deoxidizing practice in the steel-making process on the rust resistance of this steel. In this study, the factors affecting the rust resistance of $17 \%$ Cr stainless steel, especially the correlation between rust resistance during salt spray fog test and the composition of the non-metallic inclusions in the steel have been investigated.

\section{Experimental Procedures}

$17 \% \mathrm{Cr}$ stainless steels were air-melted in an Heroult type electric arc furnace with a capacity of $40 \mathrm{t}$ and were deoxidized with various amount of aluminum just prior to tapping. These steels were treated through commercial processes outlined in Fig. 1, namely they were hot rolled, bell annealed, cold rolled and finally bright annealed or pickled after annealing in a butane-fired catenary furnace. The check analyses in $\mathrm{wt}^{\%} \%$ of these steels were in the following ranges: $\mathrm{C} ; 0.05 \sim 0.07, \mathrm{Si} ; 0.36 \sim 0.61, \mathrm{Mn} ; 0.41 \sim$ $0.50, \mathrm{P} ; 0.014 \sim 0.024, \mathrm{~S} ; 0.006 \sim 0.012, \mathrm{Cr} ; 16.1 \sim$ $17.0, \mathrm{Ni} ; 0.11 \sim 0.26$

At first, specimens taken from the hot strips annealed at $850^{\circ} \mathrm{C}$ for $3 \mathrm{hr}$ were mechanically ground to about $0.01 \mathrm{~mm}$ in depth with emery paper to remove surface defects. The ground surfaces were then dry polished with \#1000 carbo-rundum paper, washed with organic solvents and dried in the stream of warm air (no water was used in the polishing pro-

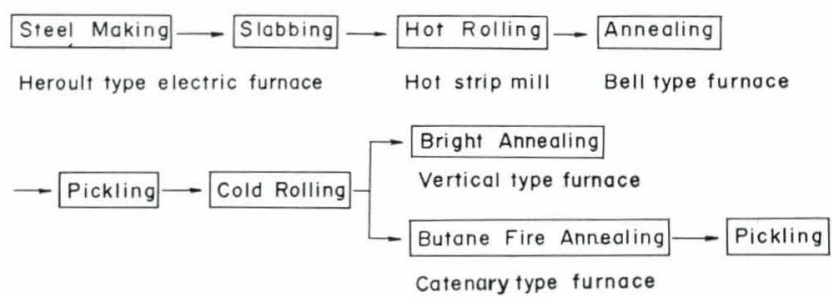

Fig. 1. Production process of the strips used in this study

* Originally published in Tetsu-to-Hagané, 57 (1971), 2152, in Japanese. English version received July 4, 1975.

** Kobe Laboratory, Research Laboratories, Kawasaki Steel Corp., Asanagi-cho, Nishinomiya 662.

*** Research Laboratories, Kawasaki Steel Corp., Kawasaki-cho, Chiba 280. 
cedure). These specimens were kept in dry air for $1 \mathrm{hr}$ and exposed in the fog of $5 \% \mathrm{NaCl}$ aqueous solution at $35^{\circ} \mathrm{C}$ for $4 \mathrm{hr}$. To make clear the initiation sites of rusting, some specimens were further polished to have a mirror finish using buff and the chromium oxide powder suspended in ethanol and exposed in salt fog for a very short time, 3 to $5 \mathrm{~min}$. The sites of rusting were observed under an optical microscope and through a scanning electron microscope (JEOL Type JSM-2).

Specimens prepared from bright annealed cold strips were exposed in salt fog without polishing. For comparison, specimens taken from butane-fire-annealed and pickled cold strips were also examined. The surface conditions of the specimens used in this work are described in Table 1. The edges of the specimens taken from cold rolled and annealed strips were covered with vinyl tape before salt fog test to prevent the additional effect due to sheared edges.

On the surfaces of the specimens after brief exposure in salt fog, the composition of the inclusions at the initiation sites of rusting and that of the ringlike rust which precipitated around these initiation sites were identified with an electron probe X-ray microanalyser (E.P.M.A.). Average contents of inclusions and of the oxygen in steel were quantitatively analysed by brome ethanol method and fusion method, respectively.

\section{Results}

\section{Susceptibility to Rusting of the Steel}

The rust resistance was classified into five grades

Table 1. Surface condition of specimen

\section{Specimens}

Annealed hot strip

\begin{tabular}{l|l|l|}
\hline & $\begin{array}{l}\text { Annealed in } \\
\text { cracked } \\
\text { ammonia gas }\end{array}$ & (1) Bright annealed \\
$\begin{array}{l}\text { Annealed } \\
\text { cold strip }\end{array}$ & $\begin{array}{l}\text { (1) } \text { Pickled } \\
\text { Annealed in } \\
\text { butane fire }\end{array}$ & (2) $\begin{array}{l}\text { Polished with \#1000 emery } \\
\text { paper }\end{array}$
\end{tabular}

(indices) as shown in Photo. 1 and Table 2 by calculating the coverage percent of rust sites, which is defined by the equation in the foot note under Table 2. In this case, the smaller index number indicates better rust resistance.

In Fig. 2, the correlation between the rust resistance of cold strip specimens having bright annealed surface and that of the mother hot strip specimen polished with \#1 000 emery paper is plotted. This suggests the existence of some latent factors which influence rust resistance. The butane-fire-annealed and pickled specimens reveal more rust resistance than the bright annealed specimens both under the as-received surface conditions. However, after dry polishing by $0.05 \mathrm{~mm}$ in depth the butane-fire-annealed and pickled specimen shows the same rust resistance as that of bright annealed one.

The correlation between rust indices of the hot strip specimens after exposure in salt fog and their total aluminum contents is shown in Fig. 3. This figure indicates that the rust resistance of the specimens becomes poorer in proportion to increase in aluminum content in the steel and that the strip containing beyond about $0.006 \%$ of $\mathrm{Al}$ tends to rust seriously. A quite simillar correlation between rust indices and acid-insoluble aluminum contents in the specimens is shown in Fig. 4.

Table 2. Corrosion index defined by surface coverage per cent of rust* on the surface of the specimen after salt fog test for $4 \mathrm{hr}$ (see Photo. 1)

\begin{tabular}{|c|c|c|c|c|c|}
\hline $\begin{array}{r}\begin{array}{r}\text { Corrosion } \\
\text { index }\end{array} \\
\text { Specimen }\end{array}$ & 1 & 2 & 3 & 4 & 5 \\
\hline $\begin{array}{l}\text { Annealed } \\
\text { hot strip }\end{array}$ & $0 \%$ & $\leq 5 \%$ & $\leq 20 \%$ & $\leq 50 \%$ & $>50 \%$ \\
\hline $\begin{array}{l}\text { Bright annealed } \\
\text { cold strip }\end{array}$ & $\leq 3 \%$ & $\leq 10 \%$ & $\leq 20 \%$ & $\leq 50 \%$ & $>50 \%$ \\
\hline
\end{tabular}

* Surface coverage per cent of rust

Number of $5 \mathrm{~mm}$ square sections rusted

Number of $5 \mathrm{~mm}$ square sections on test surface $\times 100$

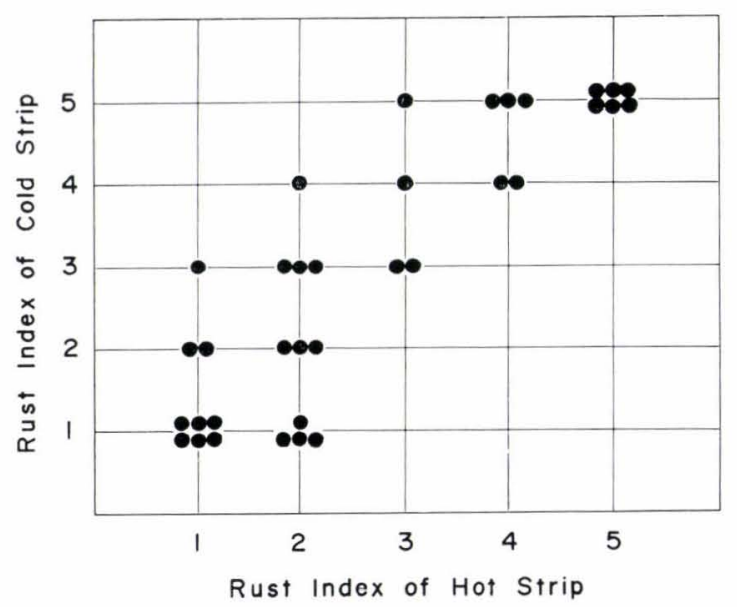

Fig. 2. Correlation between the intensity of the rusting on bright annealed cold strip and that on the mother hot strip after salt fog test for $4 \mathrm{hr}$
Photo. 1. Representative appearance of the rusting on bright annealed cold strips (see Table 2) 
Chemical analysis of non-metallic inclusions was carried out on the several specimens showing various levells of rust resistance and the obtained results are shown in Table 3 . The seriously rusted steel contains more $\mathrm{Al}_{2} \mathrm{O}_{3}$ and less $\mathrm{SiO}_{2}$.

Although the relation between rust index and total oxygen content of steels is not clear as shown in Fig. 5, there are some indications that the specimens having low oxygen contents reveal poor rust resistance.

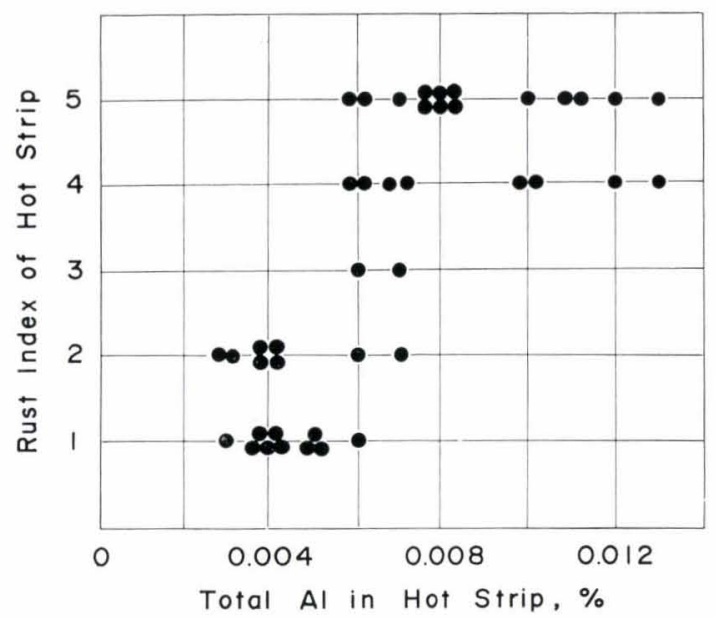

Fig. 3. Effect of total aluminum content on the rusting of annealed hot strip after exposure in salt fog test for $4 \mathrm{hr}$

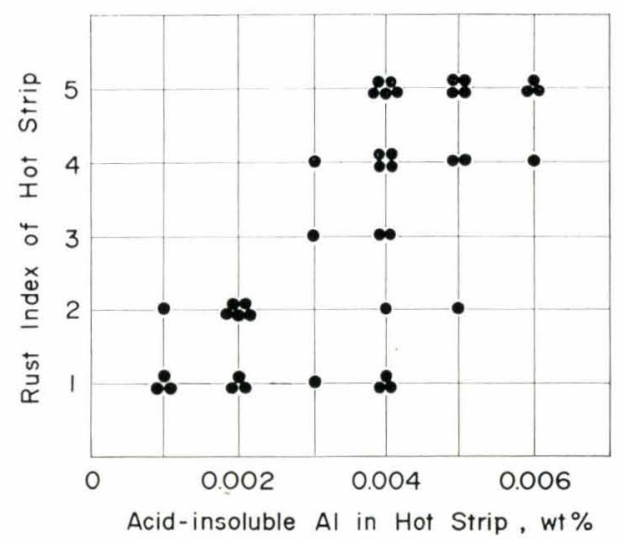

Fig. 4. Effect of acid-insoluble aluminum content on the rusting of annealed hot strip after exposure in salt fog test for $4 \mathrm{hr}$

\section{Initiation Sites of Rusting}

Under an optical microscope, only pit-hole was observed at the center of the ring-like red rust after long time exposure to salt fog test, and the initial state of rusting was hardly detected. This result was identical to both cold rolled specimens and hot rolled specimens. Accordingly, specimens prepared from hot strips and bright annealed cold strips, all having the least resistance to rusting, were polished to mirror finish and exposed in salt fog for only 3 to $5 \mathrm{~min}$. After the exposure, no rusting was found on the specimens with naked eye, but the observation under an optical microscope showed a number of very small ring-like rusts with a central micro-pit in which nonmetallic inclusion existed. Typical example of the rusting is shown in Photo. 2. Two inclusions are observed in the ring of rust in this photograph; inclusion, a, which is in the center of the ring is the initiation site of this rusting, but inclusion, b, has not been attacked. Another example of initiation site observed in detail through a scanning electron microscope is shown in Photo. 3. Crevice has been formed along the inclusion-steel boundary and the steel at the edge of the crevice has been already dissolved. In the cold rolled and bright annealed specimen of which rust index was 5, the fraction of the inclusions which induced rusting during brief exposure in salt fog was about 100 th of the total inclusions in test area $(1.5 \times$ $\left.2 \mathrm{~cm}^{2}\right)$. The inclusions which induced rusting were

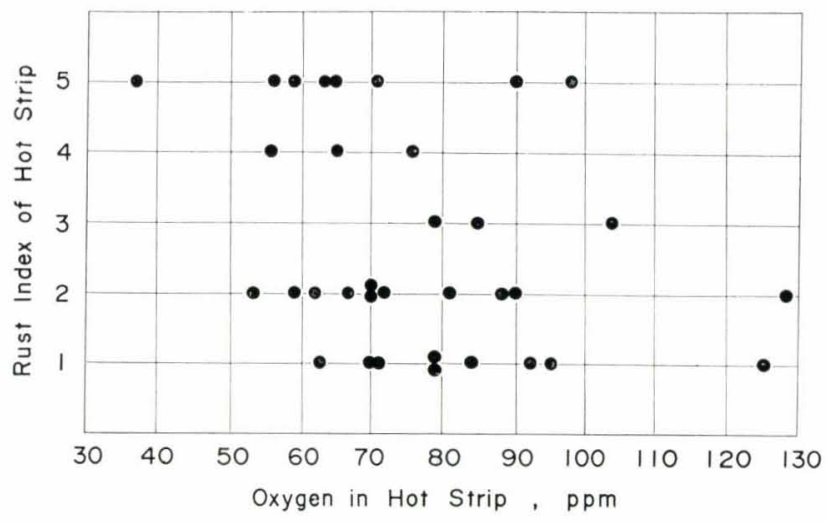

Fig. 5. Effect of oxygen content on rusting of annealed hot strip after exposure in salt fog test for $4 \mathrm{hr}$

Table 3. Results of the chemical analysis of incusions (wt \%)

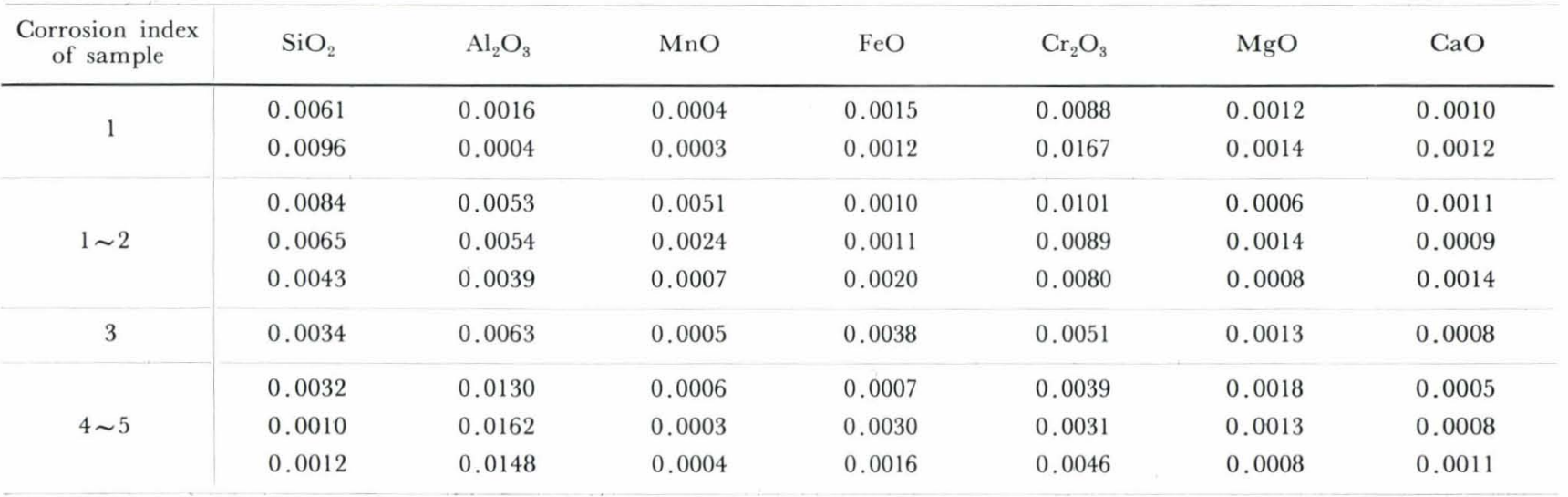


mainly so-called C-type ones as shown in Photos. 2 and 3. Some of these inclusions observed in cold strip specimens were B-type. The rusting induced by A-type inclusions was hardly observed.

The results obtained by these examinations suggest that the rusting on this steel strip during exposure in salt fog is originated at the particular sorts of inclusions. The results of line-analysis with E.P.M.A. on the inclusion shown in Photo. 3 are given in Fig. 6. Another example of the inclusion which induced rusting during brief exposure in salt fog and the results of its line-analysis are shown in Photo. 4 and Fig. 7. The line-analysis results also indicate that in the steels fully deoxidized with a lot of aluminum, the fractional content of $\mathrm{CaO}-\mathrm{Al}_{2} \mathrm{O}_{3}-$ $\mathrm{MgO}$ type of inclusion is high and that of the inclusions containing $\mathrm{SiO}_{2}$ is low. Besides this, it is important to note that the inclusions which induced rusting during exposure in salt fog were mainly com-

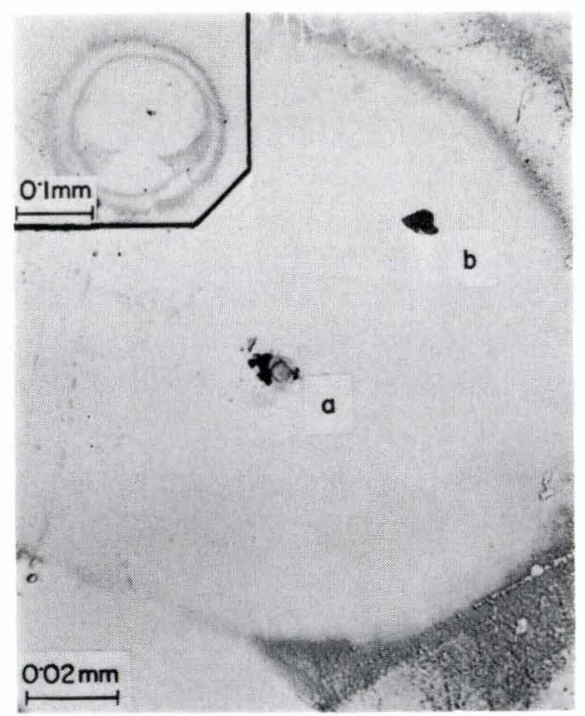

Photo. 2. Typical example of rusting after salt fog test for $3 \mathrm{~min}$. This rusting is generated from pitting due to the dissolution of inclusion, a, shown in this photograph. Inclusion, b, has not been attacked.

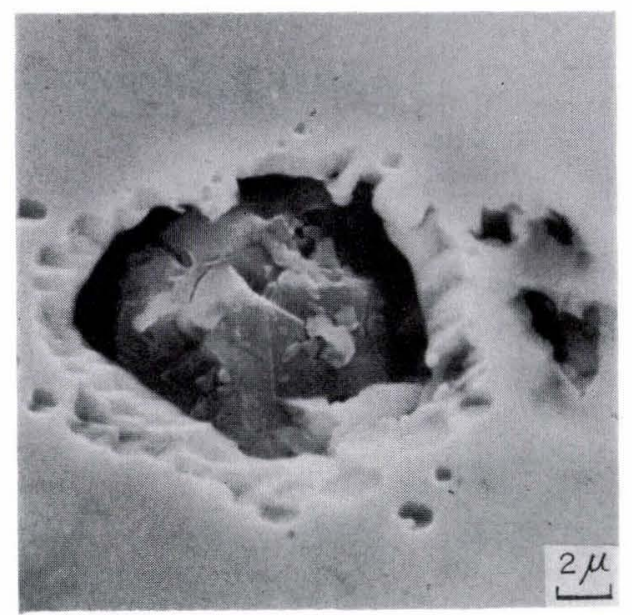

Photo. 3. Typical feature of a pitting observed through scanning electron microscope on the bright annealed cold strip specimen after salt fog test for 5 min (see Fig. 6) posed of calcium-aluminate type oxides in their cores and of sulfide, for example $\mathrm{CaS}$ or $(\mathrm{Ca}, \mathrm{Mn}) \mathrm{S}$, as a

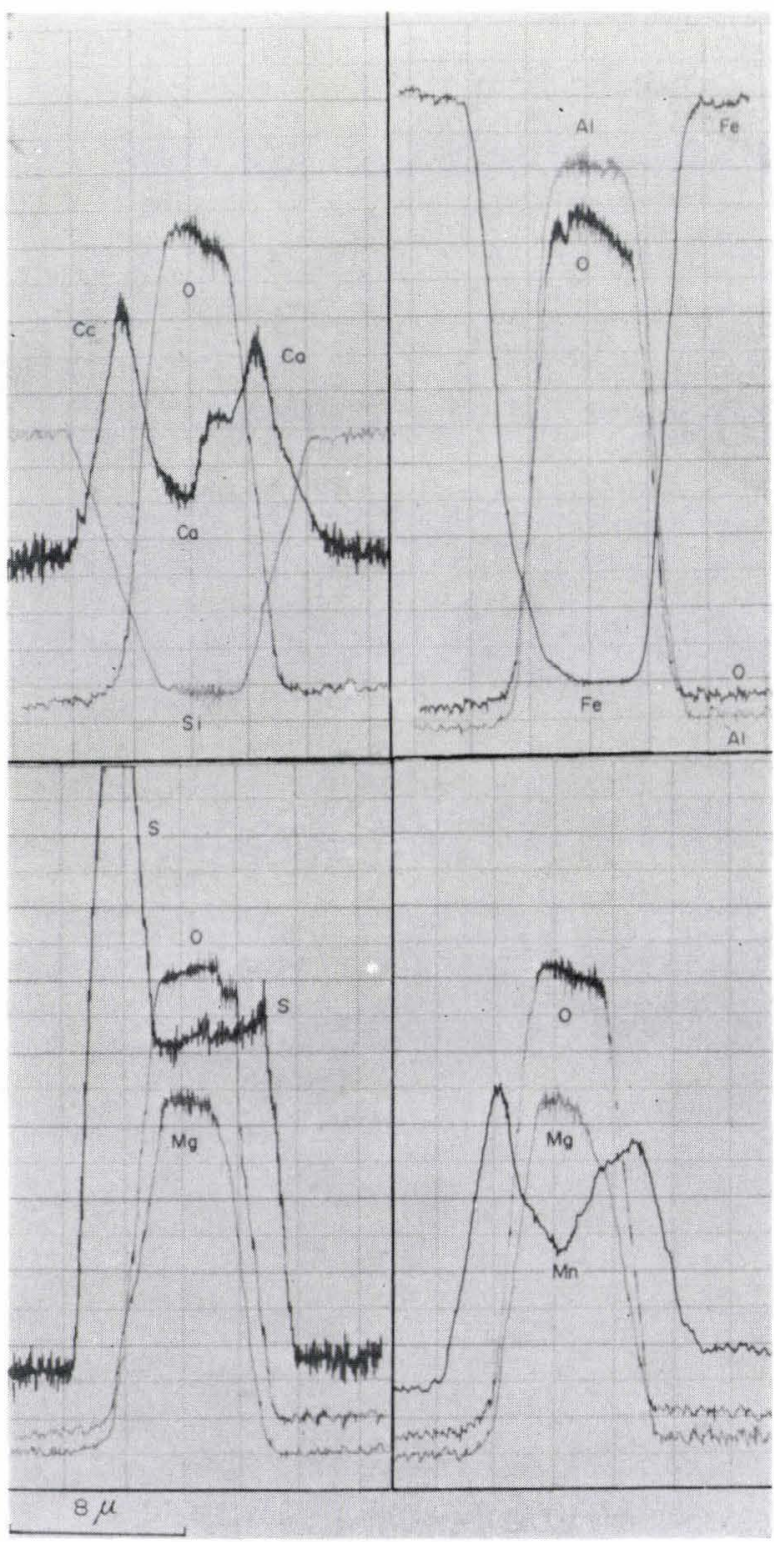

Fig. 6. Result of electron probe line-analysis of the inclussion shown in Photo 3

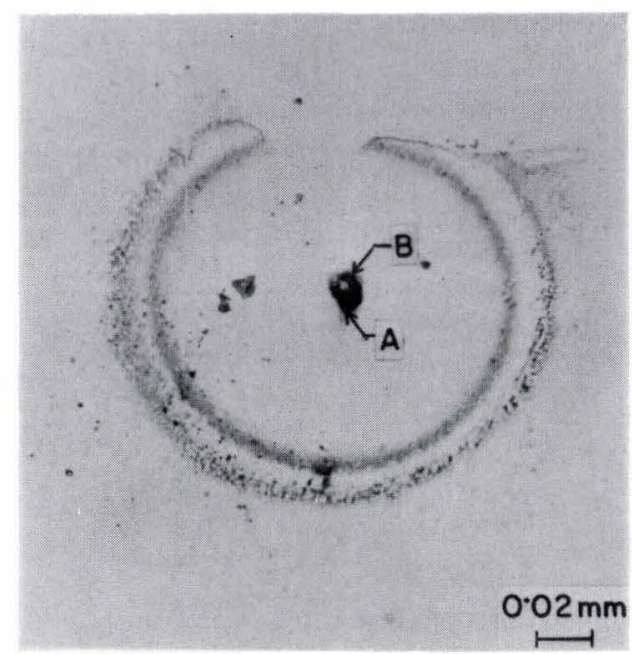

Photo. 4. Typical example of aluminate inclusion surrounded by sulfide (see Fig. 7) 
shell surrounding the oxides. There were a very few

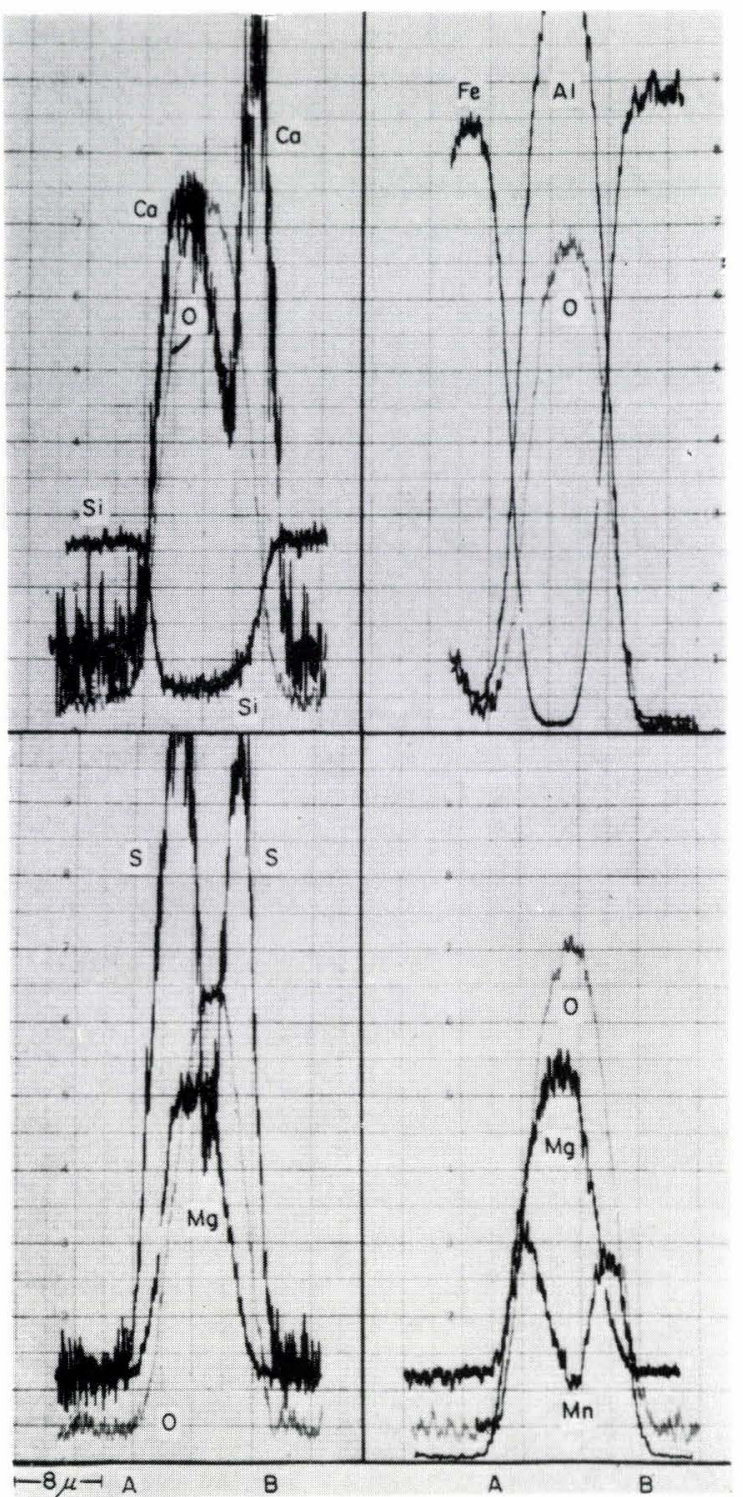

Fig. 7. Result of electron probe line-analysis of the inclusion shown in Photo. 4

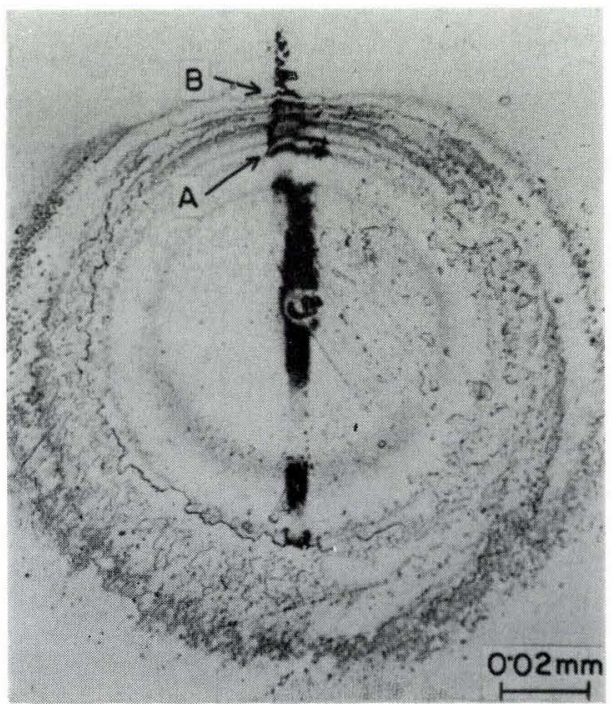

Photo. 5. Example of ring-like rust which was analysed with electron probe microanalyser (see Fig. 8) inclusions composed only of $\mathrm{CaS}$ or (Ca, Mn)S. Line-analysis with E.P.M.A. across the rust zone which is in the form of a ring around a pit showed enrichment of $\mathrm{Ca}$ and $\mathrm{S}$ (but not $\mathrm{Mn}$ ) as given in Photo. 5 and Fig. 8. This fact suggests that the sulfide, in this case, was composed mainly of $\mathrm{CaS}$ and dissolved into water and precipitated at the ring-like zone probably as $\mathrm{Ca}(\mathrm{OH})_{2}$ and FeS.

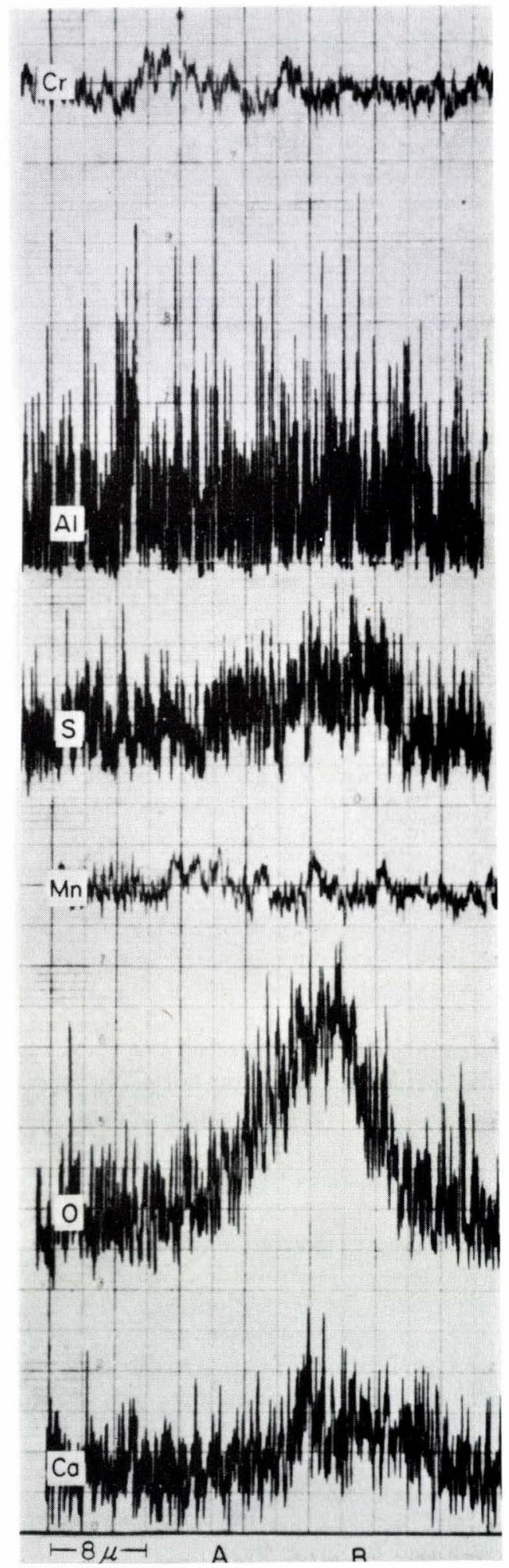

Fig. 8. Result of electron probe line-analysis of the ring-like rust around pit shown in Photo. 5 


\section{Discussion}

\section{Role of Inclusion on Rusting of Steel}

In the present study, it is suggested that the particular sorts of inclusions having high solubility in water play significant role in rusting of $17 \% \mathrm{Cr}$ stainless steel.

Wilde and Armijo ${ }^{5)}$ have shown that $14 \% \mathrm{Cr}-$ $14 \% \mathrm{Ni}$ alloys dopped with sulfur up to $0.17 \%$ were corroded by pitting at sulfide inclusions during dipping the alloys $\mathrm{FeCl}_{3}$ aqueous solution and that pitting corrosion resistance of the alloys decreases with the increase in sulfur content. Szummer, et al. ${ }^{6)}$ have pointed out that pure $16 \% \mathrm{Cr}-\mathrm{Fe}$ alloy containing no other inclusion except chromium oxides was corroded only at these inclusions. In addition, Smialowski, et al. ${ }^{7)}$ have studied the role of inclusions on the corrosion of $18.8 \% \mathrm{Cr}-9 \% \mathrm{Ni}$ stainless steel when the steel was dipped in $0.1 \mathrm{~N} \mathrm{H}_{2} \mathrm{SO}_{4}$ aqueous solution, and have found that sulfides were attacked at first and pits formed either at separated sulfide particles or at shells surrounding oxide inclusions. Recently, Kiessling and Westmann ${ }^{8}$ ) have reported that the carbon steels deoxidized with various amounts of aluminum and or calcium silicide were attacked at the (Ca, Mn) $\mathrm{S}$ inclusions lying on their surfaces when the steels were immersed into $0.1 \mathrm{~N} \mathrm{NaCl}$ aqueous solution for several minutes, and that the steels containing a large amount of aluminum were severely corroded. They showed that the steel containing ( $\mathrm{Ca}, \mathrm{Mn}) \mathrm{S}$ inclusions were severely corroded in the case of the ratio of $\mathrm{Ca}$ to $\mathrm{Ca}$ plus $\mathrm{Mn}$ in the inclusions was beyond $60 \%$.

The results obtained by present investigation on $17 \% \mathrm{Cr}$ stainless steel are essentially in agreement with these of the several studies quoted above. According to the recent work by Yano, et al. ${ }^{9)}$, some calcium-aluminates such $12 \mathrm{CaO} \cdot 7 \mathrm{Al}_{2} \mathrm{O}_{3}, 3 \mathrm{CaO} \cdot \mathrm{Al}_{2} \mathrm{O}_{3}$ and $(\mathrm{CaO})_{0.55} \cdot\left(\mathrm{Al}_{2} \mathrm{O}_{3}\right)_{0.45}$ are solube in salt water and $\mathrm{CaO}-\mathrm{Al}_{2} \mathrm{O}_{3}-\mathrm{SiO}_{2}$ type of inclusions is also soluble if their $\mathrm{SiO}_{2}$ content is less than $30 \%$. Thus these inclusions are also expected to act as an initiation site of pit corrosion during exposure in corrosive environments; however, actual pit corrosion due to these inclusions could not be observed in present experiments.

$\mathrm{CaS}$ or probably $\mathrm{CaO}-\mathrm{Al}_{2} \mathrm{O}_{3}$ type of oxides lying on the surface of steels dissolves in salt water resulting in formation of fresh surface at the crevice which becomes contact with salt water. The newly exposed steel surface at the crevice is in active state and it builds up a passive-active cell with the outer surface of the specimen. In addition, when $\mathrm{CaS}$ or ( $\mathrm{Ca}$, $\mathrm{Mn}) \mathrm{S}$ inclusion dissolves, the decomposed product, $\mathrm{HS}^{-}$or $\mathrm{S}^{2-}$, probably disturbs adsorption of oxygen to the surface of steel and consequently promotes the corrosion of steels by decreasing cathodic polarization. ${ }^{10)}$ The enrichment of $\mathrm{Ca}$ and $\mathrm{S}$ detected at the ring-like rust in present study suggests the propriety of this mechanism. A general information for mechanism on the formation of a ring-like rust has been given by Evans. ${ }^{11)}$

The difference between the rust resistance of a bright annealed strip and a pickled one can be at- tributed to that the inclusions soluble into water were already eliminated in the case of a pickled strip and that the surface of the crevice was passivated during pickling process. The superiority in rust resistance of the steel deoxidized with no or a small amount of aluminum can be explained in terms of low water solubility of $\mathrm{CaO}-\mathrm{SiO}_{2}$ type of inclusions which formed in the steel and absence of water soluble $\mathrm{CaS}$ or ( $\mathrm{Ca}, \mathrm{Mn}) \mathrm{S}$ inclusion which is often accompanied with $\mathrm{CaO}-\mathrm{Al}_{2} \mathrm{O}_{3}$ type of inclusions.

\section{Formation of (Ca, Mn)S Type of Inclusion in Steel}

Shiraiwa, et al. ${ }^{12)}$ have reported that if aluminum content in carbon steel becomes high by excess deoxidation with aluminum, sulfide inclusions tend to transform from $\mathrm{MnS}$ into (Ca, Mn)S. The similar phenomenon was observed in high carbon chromium bearing steels deoxidized with aluminum. ${ }^{13,14}$ Church, et al. ${ }^{15}$ ) have found the formation of CaS inclusion in $\mathrm{Ni}-\mathrm{Cr}-\mathrm{Mn}$ steels deoxidized in ladle with $\mathrm{Ca}-\mathrm{Si}$. Salter and Pickering ${ }^{14}$ ) have discussed the mechnaism of the formation of CaS in steels and proposed that the basic calcium-silicate inclusions brought into molten steel by mixing steel-making slag or deoxidation products dissolve sulfur and if aluminum is added in steel for further deoxidation, the silicates react with the aluminum resulting in formation of $\mathrm{CaS}$ and calcium-aluminate which has low solubility of sulfur and consequently, CaS precipitates as a shell around the calcium-aluminate inclusions. ${ }^{14)}$

In the present study, it was confirmed that the steels whose bomb samples taken just prior to tapping in the steel-making process and having much acidsoluble aluminum showed inferior rust resistance as shown in Fig. 9. This can be attributed to the reduction of silicate slag with aluminum in steel during tapping or in ladle resulting in the formation of sulfides.

\section{Compatibility of Bendability and Rust Resistance of $17 \%$ Cr Stainless Steel Strip}

With respect to bendability of $17 \% \mathrm{Cr}$ stainless

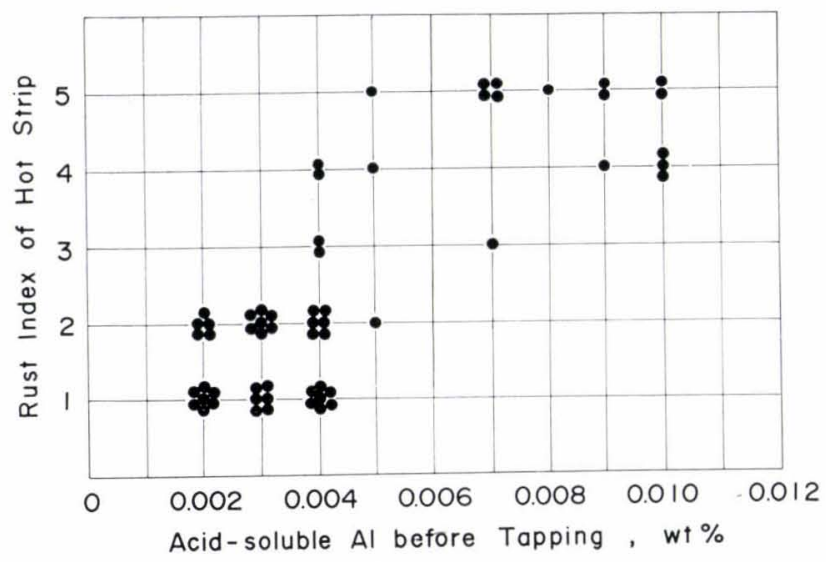

Fig. 9. Effect of acid-soluble aluminum content on rusting of annealed hot strip after exposure in salt fog test for $4 \mathrm{hr}$. Samples for chemical analysis were taken from the water quenched bomb-specimens of the molten steel just before tapping. 
steel strip, it is required that the inclusions in the steel are C-type ones, then the deoxidation with a lot of aluminum may be recommended. However, the deoxidation deteriorates the rust resistance of the steel as described above. On the other hand, calciumsilicates give no influence to rust resistance but they are harmful to bendability. That is to say, the effects of the deoxidation with aluminum on these two properties are contradictory to each other. Therefore, it is very important to control the deoxidation practice in steel-making process to make a balance of these two basic properties of $17 \% \mathrm{Cr}$ stainless steel strip.

It should be examined to control the shape of inclusions by means of other method to have another C-type of inclusion except calcium-aluminate.

\section{Conclusion}

The relation between rust resistance during exposure in salt fog and aluminum content as well as the composition of inclusion has been investigated on $17 \% \mathrm{Cr}$ stainless steel strips. The results obtained are as follows:

(1) Positive correlation has been clarified between rust resistance of the as-received specimens of bright annealed cold strips and that of the dry polished specimens of the annealed hot strips.

(2) Rusting is due to the pitting corrosion initiated at the particular sorts of inclusions having solubilities in water and lying on the surface of specimen. These inclusions are $\mathrm{CaS}$ and ( $\mathrm{Ca}, \mathrm{Mn}) \mathrm{S}$ which exist in the steel as separate particles or the shells surrounding oxides, for example, calcium-aluminates.

(3) Ca and $\mathrm{S}$ have been detected by E.P.M.A. analysis of ring-like rust which precipitated around the pit. This suggests the dissolution of sulfide from the inclusion which existed at the center of the pit.

\section{Acknowledgments}

The authors wish to thank Mr. Y. Mihara and Mr. S. Iwaoka in Nishinomiya Works, for producing the steels. The authors are grateful to Dr. K. Fujimoto, Assistant General Manager, for his valuable discussions and to Dr. K. Sanbongi, General Manager, Research Laboratories, Kwawasaki Steel Corp., for his permission to open this paper.

\section{REFERENCES}

1) S. P. Oder: Electric Furnace Proc., 18 (1960), 334.

2) I. Takashashi, M. Ogawa and T. Yosida: Tetsu-toHagané, 56 (1970), 1172.

3) A. G. Carnegie and A. Moskowitz: U. S. Patent No. 3, 247,086 (April 19, 1966).

4) N. Knoshita, N. Ohashi and M. Takeda: unpublished report of Kawasaki Steel Corp.

5) B. E. Wilde and J. S. Armijo: Corrosion, 23 (1967), 208.

6) A. Szummer, Z. Szklarska-Smialowska and M. JanikCzachor: Corros. Sci., 8 (1968), 827.

7) M. Smialowski, Z. Szklarska-Smialowska, M. Rychcik and A. Szummer: Corros. Sci, 9 (1969), 123.

8) R. Kiessling and C. Westmann: JISI, 208 (1970), 699.

9) S. Yano, K. Nakanishi and H. Ooi: Trans. ISIJ, 16 (1976), 258.

10) T. P. Hoar and D. Havenhand: JISI, 83 (1936), 239.

11) U. R. Evans: Introduction to Metallic Corrosion Edward Arnord Ltd., (1955), 29.

12) T. Shiraiwa, T. Araki and N. Fujino: Special Lecture presented at the Meeting of Special Steel Committee, Joint. Research Society, ISIJ, (1969), July.

13) Z. Bojarski, E. Barszcz, J. Bryniarska, H. Serwicki, J. Taborski and T. Terlecki: Iron Steel, 40 (1967), 304.

14) W.J. M. Salter and F. B. Pickering: JISI, 207 (1969), 992.

15) C. P. Church, T. M. Krebs and J. P. Rowe: J. Metals, 18 (1966), 62 . 